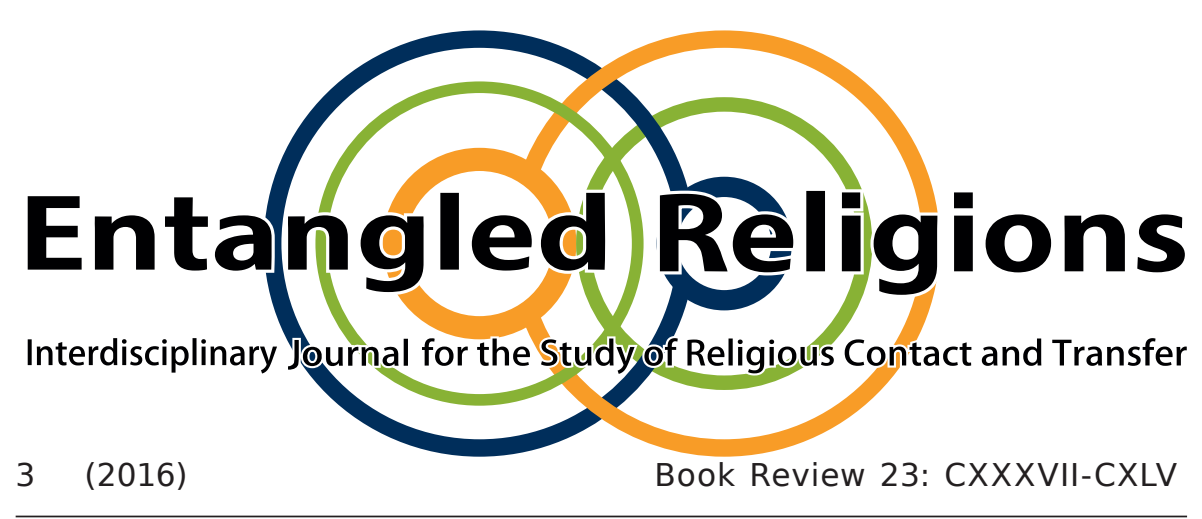

Religion in Science Fiction.

The Evolution of an Idea and

the Extinction of a Genre

London/New York: Bloomsbury Academic, 2016.

225 pages, f28.99, ISBN (paperback): 9781474273176

STEVEN HROTIC



This contribution to Entangled Religions is published under the Creative Commons Attribution-NonCommercial-NoDerivatives 4.0 International Public License (CC BY-NC-ND 4.0 International). The license can be accessed at http://creativecommons.org/licenses/ by-nc-nd/4.0/ or is available from Creative Commons, 559 Nathan Abbot Way, Stanford, California 94305, USA.



SPONSORED BY THE 


\title{
Religion in Science Fiction. The Evolution of an Idea and the Extinction of a Genre
}

London/New York: Bloomsbury Academic, 2016. 225 pages, f28.99, ISBN (paperback): 9781474273176

\author{
STEVEN HROTIC
}

The December 1933 edition of Wonder Stories featured a short story entitled The Inquisition of 6061 by the unknown author Arthur F. Jones, a good example of genre science fiction in its early stage. The story is set in a distant future which, after several world wars, is controlled by a man named $X$ whose totalitarian ideology centers on the worship of electricity. $X$ and his followers have successfully implemented control over the world and its citizens not only by horrifying them through atrocious suppression and torture (which is presented in detail), but also by forcing them to abide by the new credo of modernity: "Electricity is my God." (Jones 1933, 443)1 $J$, the story's hero, can't stand it any longer-he is afraid to lose the last bit of individuality which he sees in the freedom of personal thought:

Half believed in a Creator. There were hints that that was to go. And that was to go for the God of Electricity. The other half believed in it. It would be easy for the stubborn ones to be made to think a different way. (Jones $1933,442)$

1 This quote is from the original narrative. See Jones, Arthur F. 1933. "The Inquisition of 6061." Wonder Stories, Nr. 5/5 (December 1933): 441-446 and 531. This quote can be found on p. 443. 
J confronts the social system dominated by the new God of Electricity and sparks off a riot. In the end, as he delivers a fervent harangue against $X$ and his belief in front of the masses, the sky opens and $X$ is struck by a bolt of lightning affirming the power of another, not man-made electricity which thus frees the world and reinstates freedom of speech and religion in the same vein as J's revolt.Jones' story is representative of an early phase of genre science fiction dubbed the "Gernsback-era" (Hrotic 2016, 58) by Steven Hrotic, author of this seminal study on Religion in Science Fiction: The story is ill-written, only a few pages long, based on a simple pattern of 'good vs. bad' and promoting a hero following one of science fiction's most important values at the time: freedom of thought. Interestingly enough, its treatment of religion is rather complex given the brevity of the text: Jones differentiates between personal belief (valued by its hero J) and religion as a social system (i.e. the totalitarian 'church' of electricity) which may be used to influence and oppress people and their individual needs. The latter is the role Hrotic's account of religion in science fiction centers on: here, religion is seen "as a social system, like any other within a given domain, which is legitimated by the claim of supernatural authority" (p. 11) - a concise definition of the term which is necessary to make this book possible, given the uncountable ways in which, for example, seemingly supernatural phenomena (which might also be called 'religious') appear in science fiction.

As he does in the case of religion, Hrotic also provides a rather narrow concept of "genre science fiction" as "the cultural products of a bounded group, working in collaboration with each other" and comprising not only writers, "but also readers, editors, publishers, cover artists, etc.: the whole community whose cumulative actions affect how a bounded set of science fiction changed over time” (pp. 20f.). 'Genre science fiction' (gSF), for Hrotic, is opposed to more 'mainstream science fiction' (mSF) in that 
the latter does not necessarily belong to the same system of production and reception. Also, mSF covers themes and motifs not essential for the core of gSF and attracts a much wider readership not closely connected to the 'rules' of the genre but only familiar with its simplest outlines and subjects. ${ }^{2}$ Hrotic underlines that he writes a book of cognitive anthropology, not literary criticism. Thus, he is not interested in the texts as autonomous works of art, but only as examples of the 'metanarrative' of religion in science fiction (which makes it easier to refer to works here that are utterly 'bad literature', but relevant and representative cases of the treatment of religion in science fiction). His interest is vested in the development of the relationship of science fiction and religion within the special (mostly male, white, and American) niche it occupied from its beginning in the 1920s until its supposed end around 2000. The metanarrative he presumes can be drawn from the development of this relationship over the decades. His book is divided into four parts: firstly, he is concerned with the "mothers", "fathers" and "raw materials" in science fiction before the term was coined (pp. 5-53); secondly, he focuses on the first half of his metanarrative, ranging from the construction of the genre in the mid-1920s until the mid1960s (pp. 55-120). He completes his journey through genre science fiction in part three (pp. 121-170) before examining the metanarrative as a whole, the possible extinction of the genre and its cultural relevance in the closing part of his study (pp. 171-199).

Before there was science fiction as a genre, there was science-and religion-in other types of literature. The 'raw materials' Hrotic presents in the first part of his book are adventure novels from the $18^{\text {th }}$ and $19^{\text {th }}$

2 An opposition which is of course rather debatable: gSF itself not only takes 'mainstream' texts as its starting point, moreover, in many cases a clear line between gSF and mSF cannot be easily maintained regarding particular works.

CXL 
centuries as well as utopias from the late $19^{\text {th }}$ century onwards. He points to the idea of an interplay of gSF's "mothers" and "fathers" in the creation of the new genre: While its "fathers" were important writers of texts which anticipated themes and structures of gSF (e.g. H.G. Wells and Mary Shelley), its "mothers" were the early magazine editors who provided a platform (or "womb") (p. 25) for the development of the genre.

The real life of early gSF is administered by "intelligent designers" (p. 18 and elsewhere) choosing out of the 'pool' of raw materials depicted in the first part of the book. Hrotic stresses the particular role of Hugo Gernsback and John W. Campbell who became responsible for the early science fiction magazines Amazing Stories in 1926 and Astounding Science Fiction in 1938 respectively. Both mark the beginning of gSF in that they first popularized science fiction by reprinting existing texts by Wells, Verne, Poe and others and inspiring new writing in the same strand of ideas and the not too elaborate style of existing pulp magazines. Carving out gSF in this niche arguably led to confining the new genre to a kind of ghetto out of which it hardly managed to escape. For Hrotic, this accounted for a perfect surrounding for the development of gSF, yet at the same time made the difference in literary quality between the mainstream and gSF clear from the beginning. Religion did not play much of a role in Gernsback-style gSF, as the texts presented in Amazing and other magazines of the 1920s and 1930s are rarely interested in anything but scientific views of the world. In surprisingly many stories, however, "religion appears as a routine feature: as evidence of the barbarism of some societies or as models to which we should aspire" (p. 60), both traits being visible in The Inquisition of 6061 cited above.

Campbell, Hrotic's second 'mother' of gSF, was more than 25 years younger than Gernsback and represents a second generation of magazine editors. In Astounding Science Fiction, he rigorously implemented a more 
realistic and scientific style of stories which also increased in literary style, making the next years around World War II the 'Golden Age' of gSF. Campbell's magazine featured early appearances of today's classics of the genre, among them Lester del Rey, Robert A. Heinlein, Theodore Sturgeon, Isaac Asimov, A. E. van Vogt, and Arthur C. Clarke-and an author later departing into a different direction blending science fiction and religion named L. Ron Hubbard. The crude portrayals of religion of the Gernsback era became less frequent, while a rationalistic and more modern view of religion was promoted. Nevertheless, religion was still "held at arm's length" (p. 68) in the view of the main protagonists of the stories. Especially Robert A. Heinlein's early success was fostered by a view of religion Hrotic considers prototypical for the Golden Age schema: Here, religion appears "as a manipulative, hegemonic social tool" (p. 72). gSF of the Golden Age took up religious issues more often, characterizing religion as an entity based on misunderstandings of the world, an antagonist to science, and a tool abused by rulers to manipulate the masses-a worldview rather uncritical of science and strongly skeptical of religion as the hostile opponent of the former.

The rise of the science fiction novel was an important phenomenon in the years after WWII as authors now had better opportunities to explore their plots and fictional worlds in more detail, thus also giving room for a more elaborate depiction of religious ideas and their social relevance. Coupled with a more (albeit not thoroughly) skeptical view of scientific progress following Hiroshima, new room for a more complex view of religion emerged. "A balance", Hrotic writes, "between the two was seen as possibly desirable. [...] contemporary concerns with humanity's capacity and apparent willingness to destroy itself required re-interpretations of both ends of the spectrum." (p. 101) 
The 1960s are marked by the appearance of 'Poli-Sci-Fi', picking up on the growing political discussions of the time. With Heinlein's Stranger in a Strange Land and Frank Herbert's Dune, two important texts of the time created a new conception of religion in science fiction granting religion an important role in individuals' lives as well as in the political sphere. Thus,

\footnotetext{
in early and mid-1960s gSF, religion is neither inherently positive nor inevitably negative; rather, it is a force of nature [...] that cannot be ignored if we want to understand (individual and collective) human motivations, interpersonal ties, and societal functions (p. 117).
}

The ubiquity of religion in these novels accounts for an importance of religion which makes it less easily to be ignored or demonized as it seemed to be the case in earlier years-the picture gets much more complicated and nuanced with time.

The 1970s and 1980s seem to foster a situation in which Hrotic finds gSF at the end of the century: Religion proves to be a phenomenon that is hard to neglect, it becomes increasingly important to find a way to reconcile religion and science and thus cover the whole of humanity's needs. In the first stage, beginning around 1975, "man actively seeks out, desires, needs the myth. If he is a victim, it is by his choice" (p. 135), as Hrotic points out in regard to important texts like Ray Bradbury's The Messiah and Lawrence Manning's The Man Who Awoke. In the 1980s then, there appears to be a consensus that "a solution as simple as 'science good, religion bad'" (p. 154) will not do. The examples Hrotic cites from the 1990s provide a view on religion that even seems to make religion indispensable given the challenges of the technology-driven life mankind is to face in its future. For example, the 15-year old heroine of Octavia E. Butler's Parable of the Sower, Laura, is faced with the virtual unbearable living conditions in a 
California of the 2020s, harshly affected by climate change. Facing the social consequences of this change brought about by modern technologye.g., Oregon closing down its borders in order to prevent Californians from fleeing to its more favorable living conditions-, she decides to establish a new form of religion, embracing god as the incomprehensible agent of change from whom people may learn to adapt and endure. Religion, here, seems deeply necessary for the individual to cope with what happens to the modern world, as science and technology seem to fail in providing relief for the consequences they have caused. Other examples Hrotic includes here are David Weber's Honor of the Queen and Mary Doria Russell's The Sparrow, the latter one depicting a Jesuit priest and linguist as the hitherto unseen positive hero of a science fiction novel (after a long range of Jesuits as bad guys in earlier texts of the genre).

So, what happened to science fiction after the 1990s? With regard to older versions of the hypothesis of "the extinction of SF" (p. 173), Hrotic first offers two possible reasons which might well act together in the disappearance of gSF: First, he argues that "the metanarrative may have nowhere to go" (p. 165). As the examples from the 1990s show, the driving force of the opposition between religion and science may have ceased to exist as the novels themselves have developed different ways to deal with it in a non-conflictual way. This, Hrotic later maintains, is a point of extraordinary cultural relevance today, when we are faced with versions of "the simplistic contradiction between scientific and religious perspectives that continue to dominate political discourse; there is a valuable, broadly relevant lesson here" (p. 198). His second argument seems just as convincing: "the genre has lost much of its coherence, and boundaries between genres and to the mainstream permit considerable crossover" (p. 165)-science fiction still exists, but it has left the welldefined niche of genre and permeated the mainstream, thus losing its 
defining moments of the closed-shop atmosphere, its sealed off system of production and reception, and its mighty intelligent designers so important for the development of gSF proper. Hrotic gives a variety of reasons why this happened: the barriers between gSF and the mainstream became too permeable; an unforeseen ideological heterogeneity developed within the genre; the present lacks the intelligent designers of the kind that built up gSF; science fiction just became too big of a thing to be overseen by a single author, so that the community no longer shares the same knowledge, thus losing coherence; and science fiction dissipated into visual media, making gSF part of the mainstream by definition (cf. pp. 176-183). Further study would need to investigate this 'afterlife' of gSF and its relationship to religion in the respective fields of $\mathrm{mSF}$ in different media, a topic Hrotic does not cover in this volume.

The analysis Hrotic offers is striking, well written and interesting to read, especially given his point that many of his examples are virtually unreadable pulp for genre outsiders. Religion in Science Fiction serves as an introduction both into the origins and the history of the genre. However, the book focuses less on the texts themselves but on their overarching relevance for the discussion of religion and science in western societies as a whole: gSF provides patterns clearly reflecting the dynamics of public discourse and finding literary solutions for conflicts still unresolved beyond the realm of fiction. It is a must-read for those doing research on the subject, but it also provides highly relevant insights for all those interested in the possible ways of reconciling science and religion in our modern societies.

ROBERT WALTER-JOCHUM

Freie Universität Berlin, Germany 